opinions in this consensus statement Comment represent those of the authors writing in their personal and independent academic roles, without any direction from their governments or institutions.

Roojin Habibi, Gian Luca Burci, Thana C de Campos, Danwood Chirwa, Margherita Cinà, Stéphanie Dagron, Mark Eccleston-Turner, Lisa Forman, Lawrence O Gostin, Benjamin Mason Meier, Stefania Negri, Gorik Ooms, Sharifah Sekalala, Allyn Taylor, Alicia Ely Yamin,

*Steven J Hoffman steven.hoffman@globalstrategylab.org

Global Strategy Lab, York University, Toronto, ON M3J 1P3, Canada (RH, MC, SJH); Graduate Institute of International and Development Studies, Geneva, Switzerland (GLB); Pontificia Universidad Católica de Chile, Santiago, Chile (TCdC); University of Cape Town, Cape Town, South Africa (DC); University of Geneva, Geneva, Switzerland (SD); Keele University, Keele, UK (ME-T); University of Toronto, Toronto, ON, Canada (LF); O'Neill Institute for National and Global Health Law, Georgetown University Law Center, Washington, DC, USA (LOG); University of North Carolina at Chapel Hill, Chapel Hill, NC, USA (BMM); University of Salerno, Fisciano, Italy (SN); London School of Hygiene \& Tropical Medicine, London, UK (GO); Warwick University, Coventry, UK (SS); University of Washington, Seattle, WA, USA (AT); and Harvard University, Cambridge, MA, USA (AEY)

1 WHO. International Health Regulations, WHA 58.3, 2nd edn. Geneva: World Health Organization, 2005.

2 Tejpar A, Hoffman SJ. Canada's violation of international law during the 2014-2016 Ebola outbreak. Can Yearb Int Law 2017; 54: 366-83.

3 Vienna Convention on the Law of Treaties, May 23 1969, 1155 UNTS 331 (entered into force January 27, 1980).

4 Brownstein JS, Wolfe CJ, Mandl KD. Empirical evidence for the effect of airline travel on inter-regional influenza spread in the United States. PLoS Med 2006; 3: e401.
5 Mateus ALP, Otete HE, Beck CR, Dolan GP, Nguyen-Van-Tam JS. Effectiveness of travel restrictions in the rapid containment of human influenza: a systematic review. Bull World Health Organ 2014; 92: 868-80D.

6 Poletto C, Gomes MF, Pastore y Piontti A, et al. Assessing the impact of travel restrictions on international spread of the 2014 West African Ebola epidemic. Euro Surveill 2014; 19: 20936

7 WHO. Updated WHO advice for international traffic in relation to the outbreak of the novel coronavirus 2019-nCoV. Jan 27, 2020. http://www.who.int/ ith/2019-nCoV_advice_for_international_traffic/en/ (accessed Feb 11, 2020).

8 WHO. WHO Director-General's statement on IHR Emergency Committee on Novel Coronavirus (2019-nCoV). Jan 30, 2020. https://www.who.int/dg/ speeches/detail/who-director-general-s-statement-on-ihr-emergencycommittee-on-novel-coronavirus-(2019-nCoV) (accessed Feb 11, 2020).

9 WHO. Novel coronavirus (2019-nCoV) technical guidance. 2020. https://www.who.int/emergencies/diseases/novel-coronavirus-2019/ technical-guidance (accessed Feb 11, 2020).

10 Takahashi Y. Proportionality. In: Shelton D, ed. Oxford Handbook of International Human Rights Law. Oxford: Oxford University Press, 2013: 449

11 Yeung J. As the coronavirus spreads, fear is fueling racism and xenophobia. CNN, Jan 31, 2020. https://edition.cnn.com/2020/01/31/asia/wuhancoronavirus-racism-fear-intl-hnk/index.html (accessed Feb 11, 2020)

12 WHO. Novel coronavirus (2019-nCoV) situation report-18. Feb 7, 2020. https://www.who.int/docs/default-source/coronaviruse/situationreports/20200207-sitrep-18-ncov.pdf?sfvrsn=fa644293_2 (accessed Feb 11, 2020).

13 Hoffman SJ. The evolution, etiology and eventualities of the global health security regime. Health Policy Plan 2010; 25: 510-22.

14 Ottersen T, Hoffman SJ, Groux G. Ebola again shows the International Health Regulations are broken: what can be done differently to prepare for the next pandemic? Am J Law Med 2016; 42: 356-92.

15 Khan K, Eckhardt R, Brownstein JS, et al. Entry and exit screening of airline travellers during the $A(\mathrm{H} 1 \mathrm{~N} 1) 2009$ pandemic: a retrospective evaluation. Bull World Health Organ 2013; 91: 368-76.

\title{
@ (1) Climate change and the people's health: the need to exit the consumptagenic system
}

Published Online

February 20, 2020 https://doi.org/10.1016/ S0140-6736(20)30257-9
The world has warmed to dangerous levels and the attendant disruption to the Earth system is profound. ${ }^{3}$ The climate change-induced bushfires in Australia have resulted in almost 30 deaths, tens of thousands displaced from their homes, up to 1.25 billion animals dead, and pristine landscapes destroyed. ${ }^{2}$ Globally, there are more frequent and severe extreme weather events. ${ }^{1}$ While Australia burned, ${ }^{3}$ the worst monsoon rains in decades caused landslides and floods in Indonesia, killing at least 70 people. ${ }^{4}$ In 2019, typhoons and heatwaves killed and injured thousands of people across Africa, Japan, India, China, Europe, and the USA.

No one will be untouched by climate change, but it is not experienced equally. ${ }^{5}$ Affluent people can afford to live in insulated buildings with air conditioning and air purifiers. The poor, older people, people with disabilities, and those with pre-existing health conditions are the least able to adapt to the changing climate, unable to escape the fires and heat, and live in dwellings and environments that amplify its effects. Having lost homes or livelihoods, and fearful for the future, some people might leave their communities and perhaps their country. This will exacerbate inequities, with those who have more financial and social capital having more options.

All of this will add to existing disease burdens and premature mortality, which are unequally distributed. Now, the heart attacks, strokes, and respiratory failure resulting from the exposure of thousands of Australians to extreme heat, fires, and smoke, and the mental health aftermath are likely to overwhelm an unprepared health system. ${ }^{6}$

The Australian Government has committed AUS\$2 billion to establish a National Bushfire Recovery Agency. ${ }^{2}$ This essential response is too little, too late. Policy is needed in Australia, as elsewhere, that helps both with adaptation to the damage already done and mitigates making climate change worse.

Good social and planning policy is good climate adaptation policy. We know that long-term investment in 
front-line community services is key to ensuring resilient communities. Why then do governments cut these budgets?? We also know that to live with dignity and good health requires material resources, a sense of control over our lives, and a voice in the decisions that affect health. ${ }^{8}$ So why do many governments introduce austerity policies that widen inequities and undermine people's capacity to adapt? ${ }^{9}$

When nations attempt to recover from devastating disasters such as the Australian bushfires, they usually focus on immediate repair to the exclusion of long-term prevention. Human activity and associated greenhousegas emissions are the main causes of climate change. ${ }^{1}$ We therefore need to disrupt the consumptagenic system that encourages and rewards the exploitation of natural resources, excess production, and hyperconsumerism, and which results in climate change and health inequities.

Future policy action and advocacy must focus on the operation of the consumptagenic system. Targets should be the institutions, actors, structures, and ideas that embed, facilitate, and normalise the global dominance of a consumptagenic system addicted to growth irrespective of the environmental, social, and health costs. This focus is particularly important in the industrialised food system and in the processes of urbanisation, two central cogs in this system of excessive production and consumption. ${ }^{5}$

Disruption of this consumptagenic system requires Australia and the rest of the world to stop extracting, burning, and investing in oil, coal, gas, and other fossil fuels. There is a political opportunity for this disruption right now. The world's largest asset manager, BlackRock, has announced that it will divest of more than half a billion US dollars in thermal coal shares from all of its actively managed portfolios as part of a more active global stance on climate change. ${ }^{10}$

Providing the progressive regulatory policy framework to enable this disruption will confront stubborn resistance and challenge the power of dominant vested interests. Public interest coalitions can help push and support governments to recalibrate the power of vested interests through their harnessing of political consciousness, organised campaigns, and accountability monitoring. ${ }^{11}$ The Youth Climate Movement and Extinction Rebellion have hit a public and political nerve. ${ }^{12}$ Climate change and health alliances are essential-health professionals have knowledge, opportunity, and political leverage that can help ensure actions are taken. ${ }^{13}$

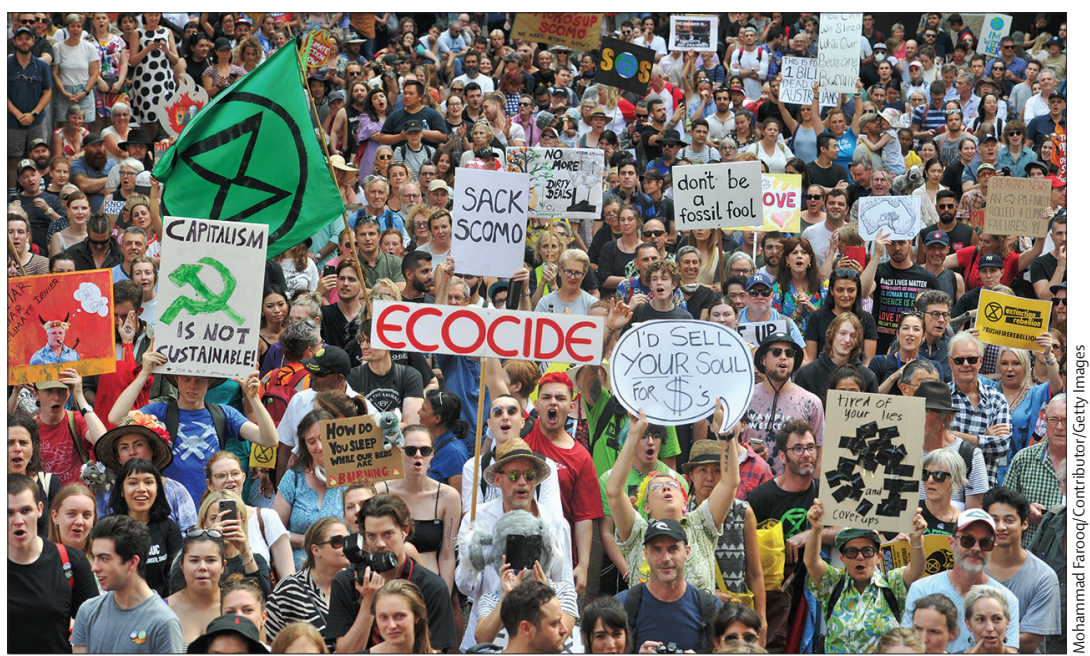

The health community must engage in policy discussions relating to the consumptagenic system ${ }^{5}$ and issues such as energy, macroeconomics, food, and infrastructure. ${ }^{14}$ Too often, health discourse retreats to the domains of health systems and individual behaviours. Acting on systemic structural factors is crucial if we are to address the common root causes of climate change and health inequities.

The bushfires in Australia, and environmental destruction elsewhere in the world, compel us to imagine a different society. Things can change, but such change requires a collective vision, courageous leadership, progressive public policy, and political struggle.

I declare no competing interests.

\section{Sharon Friel}

\section{sharon.friel@anu.edu.au}

Menzies Centre for Health Governance, School of Regulation and Global Governance, Australian National University, Canberra, ACT 2600, Australia

1 Intergovernmental Panel on Climate Change. Global warming of $1.5^{\circ} \mathrm{C}$ Geneva: Intergovernmental Panel on Climate Change, 2018.

2 The Lancet. Australia on fire. Lancet 2020; 395: 165.

3 Yu P, Xu R, Abramson MJ, Li S, Guo Y. Bushfires in Australia: a serious health emergency under climate change. Lancet Planet Health 2020; published Jan 10. https://doi.org/10.1016/S2542-5196(19)30267-0.

4 Westerman A. Monsoon rains hit Indonesia causing massive flooding in Jakarta. NPR, Jan 6, 2020. https://www.npr.org/2020/01/06/793895408/ monsoon-rains-hit-indonesia-causing-massive-flooding-in-jakarta (accessed Feb 11, 2020).

5 Friel S. Climate change and the people's health. Oxford: Oxford University Press, 2019

6 Cousins S. Bushfires expose weaknesses in Australia's health system. Lancet 2020; 395: 175-76.

7 Baum F. The new public health. Oxford: Oxford University Press, 2016.

8 Commission on the Social Determinants of Health. Closing the gap in a generation: health equity through action on the social determinants of health. Final report of the Commission on the Social Determinants of Health. Geneva: World Health Organisation, 2008.

9 Stuckler D, Basu S. The body economic: why austerity kills. London: Penguin, 2013. 
10 Boyd T. BlackRock dumps thermal coal. Financial Review, Jan 14, 2020. https://www.afr.com/companies/financial-services/blackrock-dumpsthermal-coal-20200114-p53rd0 (accessed Jan 30, 2020).

11 Buechler SM. Understanding social movements: theories from the classical era to the present. Abingdon: Routledge, 2016

12 Gunningham N. Averting climate catastrophe: environmental activism, Extinction Rebellion and coalitions of Influence. King's Law J 2019; 30: 194-202.
13 Climate and Health Alliance. Coal and health in the Hunter: lessons from one valley for the world 2015. https://www.caha.org.au/hunter_coal (accessed Jan 30, 2020).

14 Swinburn BA, Kraak VI, Allender S, et al. The global syndemic of obesity, undernutrition, and climate change: The Lancet Commission report. Lancet 2019; 393: 791-846.

\section{(1) EU migration policies drive health crisis on Greek islands}

Published Online January 13, 2020 https://doi.org/10.1016/ S0140-6736(19)33175-7

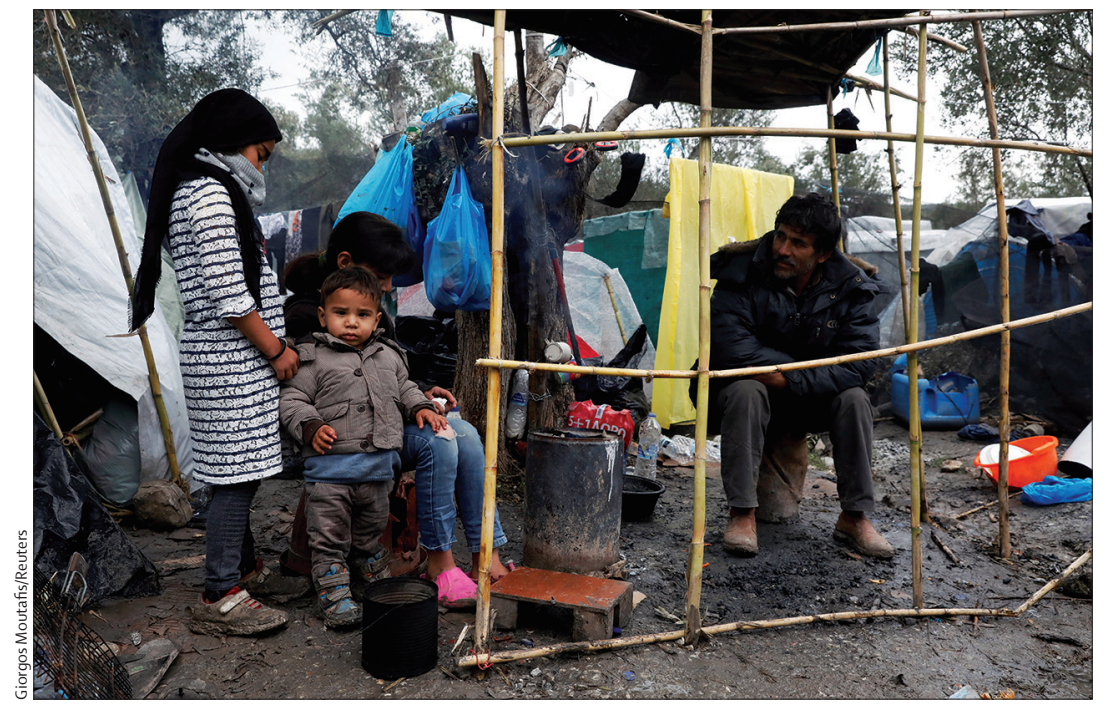

which prevents them from leaving the island unless they receive a positive decision or are deemed "vulnerable". 6 More than a third of asylum seekers are children, and there are over 1000 unaccompanied minors on Lesvos alone. ${ }^{7}$ People are forced to live in tents and under plastic sheeting even in the winter, with insufficient access to water, sanitation, and hygiene, exposing them to respiratory, skin, and gastrointestinal infections as well as environmental risks from hypothermia and fires. ${ }^{8}$

Non-governmental organisations (NGOs) working on the Greek islands, such as the International Rescue Committee and Médecins Sans Frontières (MSF), have repeatedly warned of the deterioration of health on the islands, especially the mental health distress among asylum seekers that has worsened due to the conditions of containment. The MSF clinic in Lesvos, for example, sees multiple cases of children who have self-harmed or attempted suicide and children younger than 10 years who have acute and complex mental health conditions, including one case of the rare condition resignation syndrome. 9 Alongside the burden of mental health problems, the general conditions compromise health and at least six asylum seekers have died of preventable causes on the Greek islands since August, 2019, including a 9-month-old baby who died due to dehydration. ${ }^{10}$

These conditions are not inevitable; they are the result of political choice. ${ }^{11}$ The Greek Government and EU continue to insist on the implementation of this approach. People are held in the hotspots for increasingly lengthy periods, ranging from 6 months to 1.5 years. After fleeing war and persecution in countries such as Afghanistan, Syria, or the Democratic Republic of the Congo, many are survivors of violence or torture and have faced adversity in their home countries or during migration routes. The gaps in the provision of health care mean that manageable medical and mental health conditions risk becoming more severe, posing long-term, and even life-threatening, 